\title{
2019 novel coronavirus disease with secondary ischemic stroke: two case reports
}

\author{
Bin Fu*, Yun Chen and Ping Li
}

\begin{abstract}
Background: The COVID-19 pandemic, which broke out in Wuhan in 2019, has become the global health crisis of our time. Elderly patients with certain fundamental diseases are more likely to develop severe cases. The secondary lesion following viral infection have only rarely been reported.

Case presentation: We here report two cases of coronavirus-infected pneumonia with acute ischemic stroke in middle-aged patients. In both COVID-19 cases, neurological physical examinations showed normal results before infection. Lymphocytopenia, accompanied by elevated cytokines and D-dimers, were found from serum clinical laboratory examination at admission. Dysarthria and limb muscle weakness are initial manifestations, occurring one week after infect-causative pathogen, SARS-CoV-2. The head CT and head/neck arterial CTA showed small-vessel occlusion. The patients were diagnosed with coronavirus diseases with secondary acute ischemic stroke. They were treated with tirofiban and followed up with daily aspirin and atorvastatin.
\end{abstract}

Conclusions: These cases suggested that secondary ischemic stroke, mainly manifested as small-vessel occlusion, should be considered for COVID-19 patients and diagnosed and treated promptly.

Keywords: Coronavirus disease-19 (COVID-19), Severe acute respiratory syndrome coronavirus 2 (SARS-CoV-2), Secondary ischemic stroke

\section{Background}

At the end of 2019, a novel type of coronavirus disease (COVID-19) broke out in Wuhan, China. The global number of confirmed cases of COVID-19 is still increasing daily. The main clinical manifestations of this disease are lung symptoms such as fever, cough, and wheezing [1], [2]. Patients with concomitant diseases are more likely to develop severe or critical cases and die from acute respiratory distress. Ling et al. found that 36\% of hospitalized patients had neurological manifestations like headaches and dizziness [3]. Another large-scale epidemiologic study showed that $1.5 \%$ of the COVID-19

*Correspondence: fb98@163.com; liping332008@126.com Department of Neurology, Hubei Provincial Hospital of Integrated Chinese and Western Medicine, Hubei University of Chinese Medicine, 430000 Wuhan, China patients had histories of cerebrovascular disease [1]. Nevertheless, secondary lesions following infection have only rarely reported. Here we present case reports of two confirmed middle-aged patients of COVID-19 with acute ischemic stroke. These two patients received intensive care in the isolation ward and were recently discharged from the hospital. The written consent was obtained from both patients in the consent for publication statement.

\section{Case presentation \\ Case 1}

A 45-year-old man was admitted for fever over one week on January 5, 2020. The vital signs from a general physical examination were $38.3{ }^{\circ} \mathrm{C}$ body temperature, 110 times/min for pulse, 24 times/min for breathing rate,

(c) The Author(s). 2021 Open Access This article is licensed under a Creative Commons Attribution 4.0 International License, which permits use, sharing, adaptation, distribution and reproduction in any medium or format, as long as you give appropriate credit to the original author(s) and the source, provide a link to the Creative Commons licence, and indicate if changes were made. The images or other third party material in this article are included in the article's Creative Commons licence, unless indicated otherwise in a credit line to the material. If material is not included in the article's Creative Commons licence and your intended use is not permitted by statutory regulation or exceeds the permitted use, you will need to obtain permission directly from the copyright holder. To view a copy of this licence, visit http://creativecommons.org/licenses/by/4.0/. The Creative Commons Public Domain Dedication waiver (http://creativecommons.org/publicdomain/zero/1.0/) applies to the data made available in this article, unless otherwise stated in a credit line to the data. 
and 125/72 $\mathrm{mmHg}$ for blood pressure. The patient reported no history of hypertension, diabetes, hyperlipidemia, or cardiac disease, and no history of smoking or drinking. His neurological examination on admission was normal. The clinical serum laboratory examination showed an increase in serum amyloid protein (SAA) of $288.42 \mathrm{mg} / \mathrm{L}$ (range $0-10 \mathrm{mg} / \mathrm{L}$ ), $\mathrm{C}$ reactive protein (CRP) of $25.17 \mathrm{mg} / \mathrm{L}$ (range $0-10 \mathrm{mg} / \mathrm{L}$ ), D-dimer of $15.21 \mathrm{mg} / \mathrm{L}$ (range $0-0.5 \mathrm{mg} / \mathrm{L}$ ) and fibrinogen (FIB) of $4.87 \mathrm{G} / \mathrm{L}$ (range 2-4 G/L). The levels of serum cytokines were also profoundly increased: IL- 8 increased to $438.20 \mathrm{pg} / \mathrm{ml}$ (range $0-62 \mathrm{pg} / \mathrm{ml}$ ), IL-10 increased to $836.50 \mathrm{pg} / \mathrm{ml}$ (range $0-9.1 \mathrm{pg} / \mathrm{ml}$ ), and IL-6 increased to $962.70 \mathrm{pg} / \mathrm{ml}$ (range $0-7 \mathrm{pg} / \mathrm{ml}$ ). The WBC was normal together with lymphocytopenia $(0.64 \mathrm{G} / \mathrm{L}$, range $0.8-4$ $\mathrm{G} / \mathrm{L}$ ). The levels of glucose, lipids, and homocysteine are normal. Typical bilateral patchy shadowing was observed on chest computed tomography (CT) scans (Fig. 1). The real-time RT-PCR assay for the SARS-CoV-2 test was positive.

The patient was treated with oxygen therapy, ribavirin (0.5 g, i.v. drip, Q12h), and venous rehydration solution. At 9:00 a.m. on January 6, the patient was found to have stroke symptoms, such as unclear speech, weakness of the left limb (4/5 muscle strength throughout), shallow left nasolabial groove, and tongue toward to the left. Muscle strength declined to $1 / 5$ of the upper limb and 2/5 of lower limbs at 5:00 p.m. The NIHSS score was 9 . The laboratory examination showed increased levels of D-dimer $(32 \mathrm{mg} / \mathrm{L})$ and decreased levels of FIB (1.06 G/ $\mathrm{L})$, with longer prothrombin time (PT, $14.7 \mathrm{~s}$, range 11$14 \mathrm{~s}$ ) and thrombin time (TT, $22.7 \mathrm{~s}$, range 9-20 s). However, the head CT (Fig. 2a) and neck arterial CTA (Fig. 2c and d) did not show any apparent abnormalities at that time. The patient was treated with atorvastatin (20 mg, p.o., q.d.), tirofiban ( $0.1 \mathrm{ug} / \mathrm{kg} . \mathrm{min}$, continuous intravenous pumping for 48 hours), following by daily aspirin (100 mg, p.o.) and clopidogrel (75 mg, p.o.). On

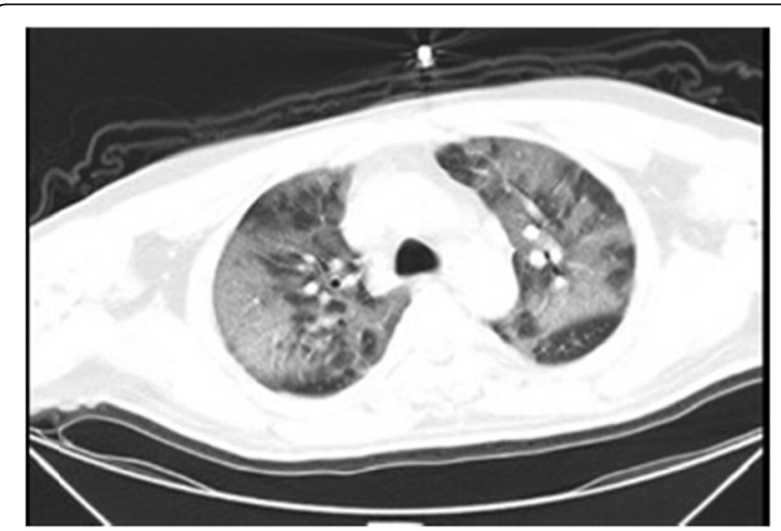

Fig. 1 CT imaging of case 1 infected with SARS-CoV-2 on January 5, 2020, Illness day 7
January 8, neurological function defects about dysarthria and left limb weakness of the patient got recovery gradually. Repeat head CT examination two days later showed infarction of the right corona radiata (Fig. 2b). The patient did not have a fever in the later of hospitalization, and his pulmonary symptoms were significantly improved. The patient was discharged from the hospital on February 3 with mild dysarthria. His left limb muscle strength score reached 5 . The NIHSS score declined to 2 from 9, and the MRS score was 1 on the discharge day.

\section{Case 2}

A 50-year-old man was admitted on February 10 for fever lasting nine days with a sudden left limb weakness lasting 28 hours. The patient had a 20-years history of smoking and did not have any history of hypertension, diabetes, hyperlipidemia, or cardiac diseases. He had undergone surgery to remove a cancerous mass from his left thyroid on January 19, 2020 in our hospital and had been discharged after recovery. The routine surgical evaluation on January 17 did not find any abnormalities from the color-Doppler ultrasound and CT angiography examinations except for basilar artery fenestration (Fig. 3a). The general physical examination at admission on February 10 was $37.8{ }^{\circ} \mathrm{C}$ for body temperature, 78 times/min for pulse, 18 times/min for breathing rate, and 132/76 mmHg for blood pressure. Neurological examinations showed shallow left nasolabial grooves, tongue toward left and dysarthria, left upper limb muscle strength score 3, and a positive reflex of Babinski's sign. The NIHSS score was 7. Laboratory examination displayed increased levels of SAA (>300 mg/L), CRP (93.15 mg/L), D-dimer (19.86 mg/L), longer PT (15.4 s) and lymphocytopenia $(0.39 \mathrm{G} / \mathrm{L})$. The levels of serum cytokines, such as IL- 8 of $84.90 \mathrm{pg} / \mathrm{ml}$, IL- $1 \beta$ of $36.60 \mathrm{pg} / \mathrm{ml}$ (range $0-5 \mathrm{pg} / \mathrm{ml}$ ) and IL-10 of $26.70 \mathrm{pg} / \mathrm{ml}$ (range $0-9.1 \mathrm{pg} / \mathrm{ml}$ ) were increased. The levels of glucose, lipids, and homocysteine were normal. The COVID-19 was diagnosed from typical bilateral patchy shadowing from chest CT (Fig. 4) and positive RT-PCR assay test. Head CT performed on February 10 presented right basal ganglia infarction (Fig. 3b). Then the patient was treated with oxygen therapy, ribavirin $(0.5 \mathrm{~g}$, i.v. drip, Q12h), and venous rehydration solution, following by daily aspirin (100 mg, p.o.), clopidogrel $(75 \mathrm{mg}$, p.o.) and atorvastatin (20 mg, p.o.). During hospitalization, the patient's fever ceased and did not recur, and the pulmonary symptoms were markedly relieved. However, defects in neurological function recovered only gradually. The patient was discharged on March 1 with mild dysarthria. The left limb muscle strength score was 4 , the NIHSS score was 5, and the MRS score was 3. 

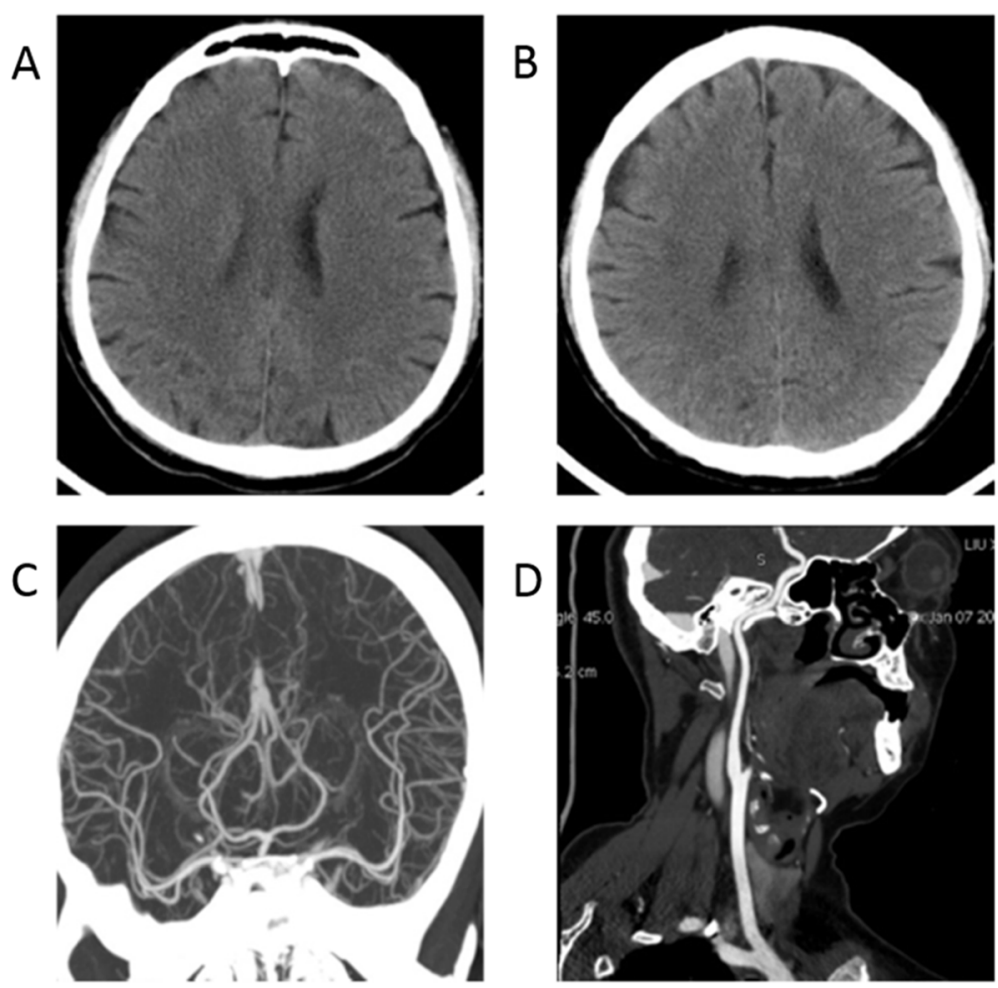

Fig. 2 The head CT and head/neck arterial CTA of case 1 infected with SARS-CoV-2. a: Head CT on January 6, 2020, IIIness day 8, b: Repeat head CT on January 8, 2020, IIIness day 10; c: Head arterial CTA on January 6, 2020, IIIness day 8, d: Neck arterial CTA on January 6, 2020, IIIness day 8

\section{Discussion and conclusion}

We report two cases of COVID-19 in patients with acute ischemic stroke. Previous studies have found that multiple organs other than the lung were also involved in COVID-19 [4]. Recently $\mathrm{Hu}$ et al. reported that neurological symptoms developed in one-third of hospitalized patients [3]. Other studies of coronavirus induced diseases (such as SARS [5], MERS [6]) also involved cases of central nervous system damage.

For both patients, neurological physical examination showed normal results before SARS-CoV-2 infection. Our initial speculation for this acute ischemic stroke is a secondary lesion one week after COVID-19 onset. The possible mechanism might involve the way that the coronavirus attacks the human body through the angiotensin-converting enzyme-2 [7] which is distributed on blood vessels and multiple organs [8]. The virus triggers a cytokine cascade that could aggravate ischemic brain damage and increase the risk of intracerebral hemorrhage [9] and blood coagulation disturbances. This hypothesis is supported by the high expression of cytokines and D-dimers observed in these two patients. Recently, many works have shown that the virus can cause thrombosis in the lungs and subsequent multiorgan failure [10]. Even the biological mechanisms underlying the elevated level of plasma D-dimers in
COVID-19 patients are unclear [11]. Thachil et al. suggested that low molecular weight heparin (LMWH) at prophylactic doses should be beneficial for patients with markedly elevated D-dimers [12]. Notably, these two patients were middle-aged and should had a low risk of stroke. They did not show any symptoms of deep venous thrombosis or large vessel occlusion with endoluminal thrombosis. We suspected that the small-vessel occlusion was secondary lesion following coagulopathy during SARS-CoV-2 infection. Unfortunately, we could not have more exhaustive neurological examinations during this hospitalization because of the exceptional infectious circumstances. Thus, there are still some concerns about increased D-dimer levels and ischemic stroke or thrombosis in multiple organs from a clinical perspective.

In case 1 , we addressed the possibility of small-vessel occlusion developing into progressive stroke, using tirofiban instead of aspirin and clopidogrel. We did so with the informed consent of the patient and acted in accordance with the Chinese expert consensus on the clinical use of tirofiban in atherosclerotic cerebrovascular diseases [13] and guidelines for the early management of patients with acute ischemic stroke [14]. The patient's neurological function recovered rapidly over 2 days. Such platelet glycoprotein II.b/III.a receptor antagonists could act on the final common channel of thrombosis. 

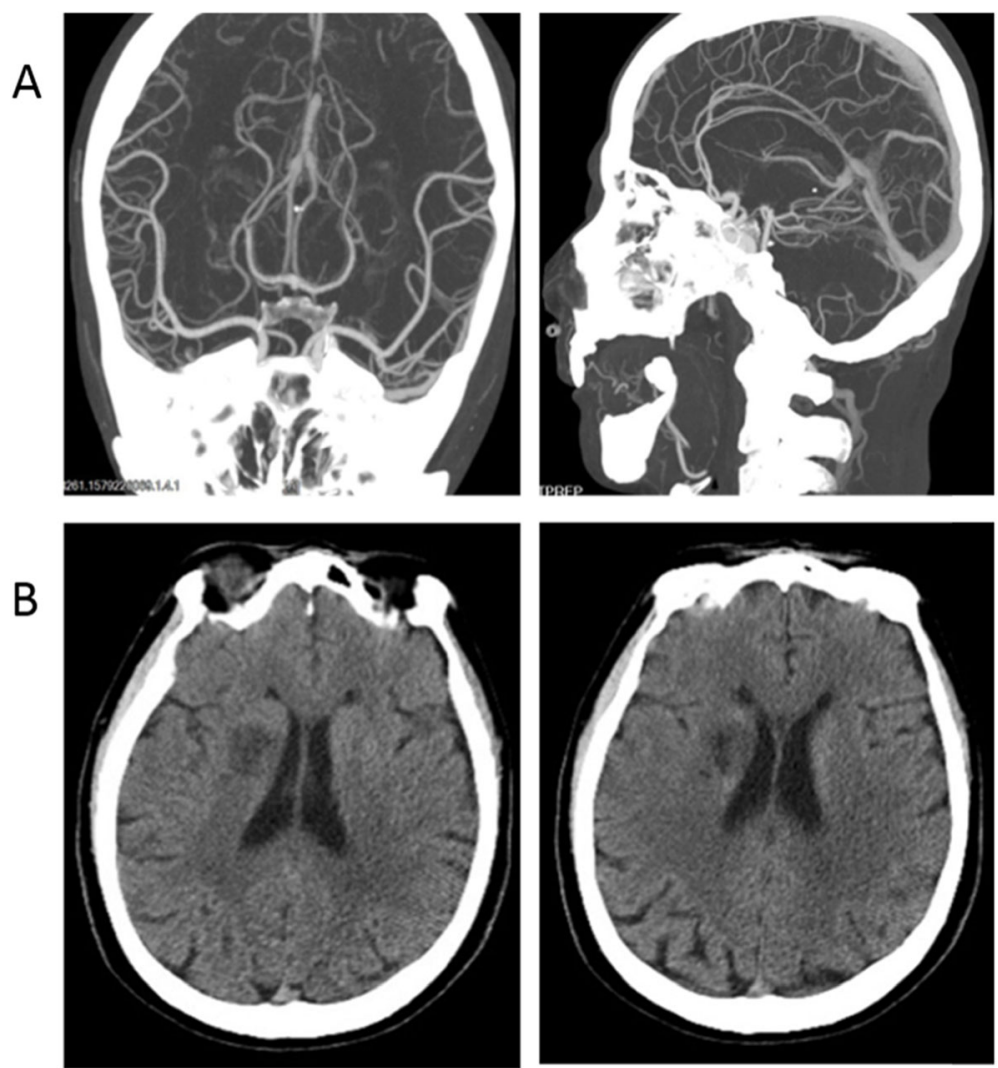

Fig. 3 The head/neck atrial CTA and head CT of case 2 infected with SARS-CoV-2. a: Head CTA on January 17, 2020, routine surgical evaluation before thyroid cancer removal surgery, b: Head CT on February 10, 2020, Illness day 9

Their efficacy was found to have no significant difference from aspirin in the incidence of symptomatic intracranial hemorrhage $[15,16]$. It is important to note that the LMWH can reduce the risk of thromboembolism in our case with hypomobility according to the new consensus [17].

These are the only two reported cases of COVID-19 with secondary acute ischemic stroke out of 764

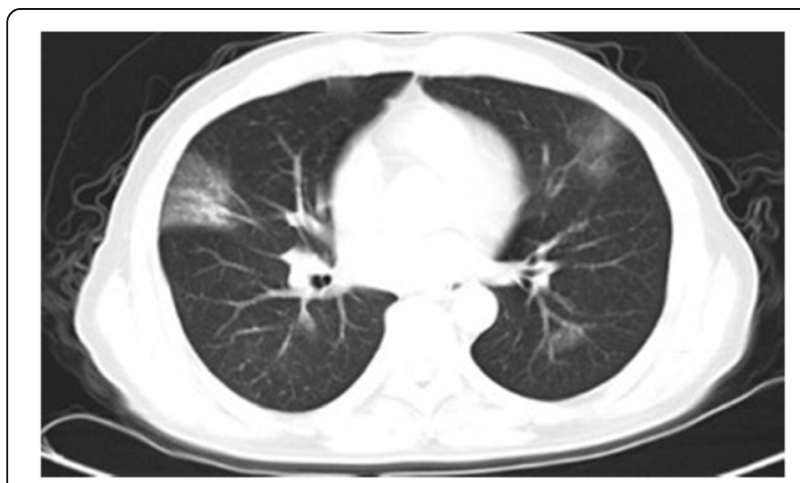

Fig. 4 CT imaging of case 2 infected with SARS-CoV-2 on February10, 2020, IIIness day 9 hospitalized patients in Hubei Provincial Hospital of Integrated Chinese and Western Medicine until March 9, 2020. We suggest early diagnosis and treatment should be considered for COVID-19 patients with secondary ischemic stroke, which manifests mainly as small-vessel occlusion.

\section{Abbreviations}

COVID-19: Coronavirus disease-19; SARS-CoV-2: Severe acute respiratory syndrome coronavirus 2; CT: Computed tomography; CTA: Computerized tomography angiography; RT-PCR: Reverse transcription-polymerase chain reaction; SAA: Serum amyloid protein; FIB: Fibrinogen; CRP: C reactive protein; PT: Prothrombin time; TT: Thrombin time; NIHSS: National Institutes of Health Stroke Scale; MRS: Modified Rankin Score; WBC: White blood cell

\section{Acknowledgements}

The authors sincerely thank all colleagues of the division of neurology in the Hubei Provincial Hospital of Integrated Chinese and Western Medicine.

\section{Declarations}

Not applicable.

\section{Authors' contributions}

B.F. collected data. B.F and P.L. wrote the manuscript. B.F, Y.C, P.L. were responsible for the clinical management of the patient. All authors revised the manuscript and approved the final version.

\section{Funding}

This work received a grant from the State Administration of Traditional Chinese Medicine of Major refractory diseases pilot project of clinical 
collaboration with Chinese \& Western Medicine (Grant number SATCM20180339). The funders had no role in the study design, data collection and interpretation, and manuscript preparation.

\section{Availability of data and materials}

No datasets were analyzed during the current study.

\section{Ethics approval and consent to participate}

Not applicable.

\section{Consent for publication}

The written consent for publication was obtained from both patients in the consent for publication statement. Copy of the written consent is available for review by the editor of this journal.

\section{Competing interests}

The authors state that they have no conflicts of interest.

Received: 22 March 2020 Accepted: 21 December 2020

Published online: 05 January 2021

\section{References}

1. Guan WJ, Ni ZY, Hu Y, Liang WH, Ou CQ, He JX, et al. Clinical Characteristics of Coronavirus Disease 2019 in China. N Engl J Med. 2020;382 18:1708-20. doi:https://doi.org/10.1056/NEJMoa2002032.

2. Wang D, Hu B, Hu C, Zhu F, Liu X, Zhang J, et al. Clinical Characteristics of 138 Hospitalized Patients With 2019 Novel Coronavirus-Infected Pneumonia in Wuhan, China. Jama. 2020. doi:https://doi.org/10.1001/jama.2020.1585.

3. Mao L, Jin H, Wang M, Hu Y, Chen S, He Q, et al. Neurologic Manifestations of Hospitalized Patients With Coronavirus Disease 2019 in Wuhan, China. JAMA Neurology. 2020. https://doi.org/10.1001/jamaneurol.2020.1127.

4. Wang T, Du Z, Zhu F, Cao Z, An Y, Gao Y, et al. Comorbidities and multiorgan injuries in the treatment of COVID-19. Lancet. 2020. doi:https://doi. org/10.1016/s0140-6736(20)30558-4

5. Morfopoulou S, Brown JR, Davies EG, Anderson G, Virasami A, Qasim W, et al. Human Coronavirus OC43 Associated with Fatal Encephalitis. N Engl J Med. 2016:375 5:497-8. doi:https://doi.org/10.1056/NEJMc1509458.

6. Algahtani H, Subahi A, Shirah B. Neurological Complications of Middle East Respiratory Syndrome Coronavirus: A Report of Two Cases and Review of the Literature. Case Rep Neurol Med. 2016;2016:3502683. doi:https://doi.org/ $10.1155 / 2016 / 3502683$

7. Li W, Zhang C, Sui J, Kuhn JH, Moore MJ, Luo S, et al. Receptor and viral determinants of SARS-coronavirus adaptation to human ACE2. EMBO J. 2005:24 8:1634-43. doi:https://doi.org/10.1038/sj.emboj.7600640.

8. Hamming I, Timens W, Bulthuis MLC, Lely AT, Navis GJ, van Goor H. Tissue distribution of ACE2 protein, the functional receptor for SARS coronavirus. A first step in understanding SARS pathogenesis. J Pathol. 2004;203 2:631-7. doi:https://doi.org/10.1002/path.1570.

9. Muhammad S, Haasbach E, Kotchourko M, Strigli A, Krenz A, Ridder Dirk A, et al. Influenza Virus Infection Aggravates Stroke Outcome. Stroke. 2011;42 3:783-91. doi:https://doi.org/10.1161/STROKEAHA.110.596783.

10. Lax SF, Skok K, Zechner P, Kessler HH, Kaufmann N, Koelblinger C, et al. Pulmonary Arterial Thrombosis in COVID-19 With Fatal Outcome: Results From a Prospective, Single-Center, Clinicopathologic Case Series. Ann Intern Med. 2020. doi:https://doi.org/10.7326/m20-2566.

11. McGonagle D, O'Donnell JS, Sharif K, Emery P, Bridgewood C. Immune mechanisms of pulmonary intravascular coagulopathy in COVID-19 pneumonia. The Lancet Rheumatology. 2020;2 7:e437-e45. doi:https://doi. org/10.1016/S2665-9913(20)30121-1.

12. Thachil J. The versatile heparin in COVID-19. J Thromb Haemost. 2020;18 5: 1020-2. doi:https://doi.org/10.1111/jth.14821.

13. Yang M, Huo X, Miao Z, Wang Y. Platelet Glycoprotein Ilb/Illa Receptor Inhibitor Tirofiban in Acute Ischemic Stroke. Drugs. 2019;79 5:515-29. doi: https://doi.org/10.1007/s40265-019-01078-0.

14. Powers WJ, Rabinstein AA, Ackerson T, Adeoye OM, Bambakidis NC, Becker K, et al. Guidelines for the Early Management of Patients With Acute Ischemic Stroke: 2019 Update to the 2018 Guidelines for the Early Management of Acute Ischemic Stroke: A Guideline for Healthcare Professionals From the American Heart Association/American Stroke Association. Stroke. 2019:50(12):e344-418. doi:https://doi.org/10.1161/str. 0000000000000211.
15. Junghans U, Seitz RJ, Aulich A, Freund HJ, Siebler M. Bleeding risk of tirofiban, a nonpeptide GPIlb/Illa platelet receptor antagonist in progressive stroke: an open pilot study. Cerebrovascular diseases (Basel, Switzerland). 2001;124:308-12; doi: https://doi.org/10.1159/000047726.

16. Torgano G, Zecca B, Monzani V, Maestroni A, Rossi P, Cazzaniga M, et al. Effect of intravenous tirofiban and aspirin in reducing short-term and longterm neurologic deficit in patients with ischemic stroke: a double-blind randomized trial. Cerebrovasc Dis. 2010;29(3):275-81. doi:https://doi.org/10. $1159 / 000275503$.

17. Bikdeli B, Madhavan MV, Jimenez D, Chuich T, Dreyfus I, Driggin E, et al. COVID-19 and Thrombotic or Thromboembolic Disease: Implications for Prevention, Antithrombotic Therapy, and Follow-Up: JACC State-of-the-Art Review. J Am Coll Cardiol. 2020;75 23:2950-73. doi:https://doi.org/10.1016/j. jacc.2020.04.031

\section{Publisher's Note}

Springer Nature remains neutral with regard to jurisdictional claims in published maps and institutional affiliations.
Ready to submit your research? Choose BMC and benefit from:

- fast, convenient online submission

- thorough peer review by experienced researchers in your field

- rapid publication on acceptance

- support for research data, including large and complex data types

- gold Open Access which fosters wider collaboration and increased citations

- maximum visibility for your research: over $100 \mathrm{M}$ website views per year

At BMC, research is always in progress.

Learn more biomedcentral.com/submissions 